\title{
KARAKTERISTIK SOSIAL EKONOMI YANG MEMPENGARUHI LITERASI KEUANGAN SERTA DAMPAKNYA TERHADAP MANAJEMEN KEUANGAN PERSONAL (Survei Pada Pegawai Negeri Sipil Daerah di Kabupaten Kuningan)
}

\author{
Herma Wiharno \\ Universitas Kuningan \\ (wiharnoherma@yahoo.co.id)
}

\begin{abstract}
The purpose of this study was to assess the socioeconomic characteristics that influence financial literacy and the influence of financial literacy towards personal financial management. The financial literacy in this study was divided into dimensions of financial literacy, financial behavior, and financial attitudes.

The method used is descriptive and verificative methods. This research was conducted in the Kuningan Regency, and the Regional Civil Servants were the units of analysis. The samples used in this study were 390 Regional Civil Servants with the sample collection technique of proportional stratified cluster random sampling.

The results of the verificative analysis revealed that only education levels significantly affect the financial knowledge, while having a significant effect on the behavior and attitudes in addition to the level of financial education is also a place to stay. Financial knowledge, financial behaviors, and financial attitudes significantly influence towards the personal financial management. In relation between socioeconomic characteristics with personal financial management, education level only that significant effect on personal financial management.
\end{abstract}

Keywords: socioeconomic characteristics, financial literacy, financial knowledge, financial attitudes, financial behavior, personal financial management

\section{PENDAHULUAN}

Setiap manusia senantiasa memiliki tujuan untuk mencapai kesejahteraan yang dapat diukur berdasarkan jumlah kekayaan yang dimiliki, terpenuhinya berbagai kebutuhan hidup, tingkat pendidikan yang tinggi, jenjang karier dan jabatan yang dicapai, penyiapan generasi penerus keluarga dan lain-lain. Pendapatan adalah sesuatu yang penting dalam upaya mencapai kesejahteraan, namun besarnya pendapatan belum menjadi jaminan seseorang dapat mencapai kesejahteraan hidup.

Manajemen keuangan personal merupakan hal yang sangat penting dalam upaya mencapai kesejahteraan. Kegagalan dalam mengelola keuangan akan memicu munculnya masalah kesulitan keuangan yang selanjutnya akan berdampak pada kegagalan dalam mencapai kesejahteraan. Parrotta \& Johnson (1998) mengatakan bahwa kesulitan keuangan dan ketidakpuasan dengan status keuangan seseorang dapat menyebabkan konflik keluarga dan perceraian.

Manajemen keuangan personal dapat didefinisikan sebagai suatu proses mengelola uang untuk mencapai kepuasan ekonomi atau kesejahteraan personal (Kapoor,Dlabay \& Hughes, 2012). Jump\$tart Coalition for Personal Financial Literacy (2007) 
menjelaskan bahwa keuangan personal menggambarkan prinsip-prinsip dan metode-metode yang digunakan individu untuk mendapatkan dan mengelola pendapatan dan kekayaan. Parrotta \& Johnson (1996) mendefinisikan pengelolaan keuangan (financial managenment) sebagai bentuk perilaku yang menyangkut perencanaan, implementasi dan evaluasi tentang kas, kredit, investasi, asuransi, dan perencanaan tingkat hidup dan perencanaan masa pensiun.

Banyak faktor yang dapat menentukan keberhasilan seseorang dalam melakukan pengelolaan keuangan. Dalam risetnya Nyamute (2010) meneliti tentang pengaruh literasi keuangan terhadap manajemen keuangan personal dengan unit analisisnya para pegawai lembaga keuangan dan perbankan. Hasil penelitiannya menunjukkan bahwa terdapat perbedaan yang signifikan antara manajemen keuangan personal responden yang memiliki literasi keuangan dengan yang tidak. Responden yang memilki literasi keuangan memiliki apresiasi dan aplikasi yang lebih baik dalam manajemen keuangan personal sehingga disimpulkan bahwa literasi keuangan mempengaruhi manajemen keuangan personal.

Literasi keuangan dapat didefinisikan sebagai kemampuan membaca, menganalisis, mengelola dan mengkomunikasikan kondisi keuangan personal (Personal financial) yang mempengaruhi kesejahteraan. Literasi keuangan mencakup kemampuan membedakan pilihan pembiayaan, mendiskusikan isu keuangan tanpa kekhawatiran, merencanakan masa depan dan merespon secara kompeten kejadian hidup yang mempengaruhi keputusan keuangan sehari-hari, yang meliputi kejadian dalam perekonomian secara umum (Vitt dkk., 2000)

Atkinson dan Messy (2012) dari OECD menyatakan bahwa literasi keuangan merupakan kombinasi dari pengetahuan keuangan (financial knowledge), sikap keuangan (financial attitude), dan perilaku keuangan (financial behavior). Pengetahuan keuangan (Financial knowledge) adalah pemahaman istilah dan konsep keuangan yang diperlukan untuk digunakan sehari-hari dalam kehidupan bermasyarakat (Bowen, 2003). Sikap keuangan adalah aplikasi prinsip-prinsip keuangan untuk menciptakan dan memelihara nilai melalui pembuatan keputusan dan pengelolaan sumber daya sebaik-baiknya (Rajna, 2011). Perilaku keuangan (financial behavior) didefinisikan sebagai perilaku manusia dalam hubungannya dengan pengelolaan uang (Xiao, 2009).

Tingkat literasi keuangan masyarakat atau kelompok masyarakat berbeda antara yang satu dengan yang lainnya. Perbedaan ini disebabkan, salah satunya, karena adanya perbedaan karakteristik sosial ekonomi atau banyak peneliti yang menyebutnya dengan karakteristik demografi.

Penelitian ini dilakukan dengan tujuan untuk mengkaji baik secara simultan maupun parsial pengaruh variabel karakteristik sosial ekonomi terhadap literasi keuangan, pengaruh literasi keuangan terhadap manajemen keuangan personal, dan pengaruh variabel karakteristik sosial ekonomi terhadap manajemen keuangan personal.

\section{KERANGKA PEMIKIRAN}

Hubungan Antara Karakteristik Sosial Ekonomi dengan Literasi Keuangan

Terdapat beberapa faktor yang 
berkaitan dengan tingkat literasi keuangan, salah satunya adalah karakteristik sosial ekonomi. Karakteristik sosial ekonomi menyangkut masalah usia, gender, tingkat pendidikan, tempat tinggal, golongan gaji, dan tingkat pendapatan.

Worthington (2004) menemukan bahwa orang yang berusia 50-60 tahun kemungkinan besar tingkat literasi keuangan-nya kurang. Almenberg dan Säve-Söderbergh (2011) menemukan bahwa di Swedia tingkat literasi tertinggi ditunjukkan oleh yang berusia 35-50 tahun dan yang lebih tua dari 65 tahun ditemukan menunjukkan yang terburuk. Cole dkk. (2008) menemukan bahwa usia adalah faktor yang signifikan menjelaskan literasi keuangan. Atkinson dan Messy (2012) dari OECD menunjukkan bahwa di kebanyakan negara, usia menengah (30-60 th) memiliki tingkat literasi keuangan yang tinggi sedangkan usia yang lebih muda dan lebih tua memiliki tingkat literasi yang rendah.

Mandell (2008), Cole dkk. (2008), Worthington (2004), Chen dan Volpe (1998), Lusardi dan Mitchell (2006, 2008), Almenberg dan SäveSöderbergh (2011), Monticone (2009) menunjukkan bahwa laki-laki dibanding perempuan lebih tinggi tingkat literasi keuangan-nya. Atkinson dan Messy (2012) dari OECD menunjukkan bahwa perempuan memiliki tingkat pengetahuan keuangan dan behavior yang lebih rendah dibanding dengan laki-laki dan memiliki tingkat sikap keuangan yang lebih tinggi dibanding laki-laki.

Cole dkk. (2008), Worthington (2004), Lusardi dan Mitchell (2006, 2008), Almenberg dan Säve-Söderbergh (2011), Guiso dan Jappelli (2005) menemukan bahwa orang yang berpendidikan lebih tinggi memiliki tingkat literasi yang lebih tinggi dibanding dengan yang berpendidikan rendah. Atkinson dan Messy (2012) dari OECD menemukan adanya hubungan positif antara pendidikan dengan literasi keuangan. Orang yang berpendidikan tinggi memiliki tingkat pengetahuan keuangan, perilaku keuangan, dan sikap keuangan yang lebih tinggi.

Cole dkk. (2008) menunjukkan bahwa tempat tinggal mempengaruhi tingkat literasi keuangan. Orang yang tinggal di pedesaan menunjukkan tingkat literasi keuangan terendah. Worthington (2006), menunjukkan bahwa Literasi keuangan tertinggi untuk responden dengan tingkat pendapatan yang lebih tinggi.

\section{Hubungan Antara Literasi Keuangan Dengan Manajemen Keuangan Personal}

Keberhasilan atau kegagalan seseorang dalam mengelola keuangan personalnya sangat ditentukan oleh tingkat literasi keuangan yang dimilikinya. Semakin tinggi tingkat literasi keuangan seseorang maka akan semakin baik tingkat manajemen keuangan personalnya, dan sebaliknya semakin rendah tingkat literasi keuangan seseorang maka akan semakin buruk tingkat manajemen keuangan personalnya.

Literasi keuangan merupakan kombinasi dari: (1) pengetahuan keuangan (financial knowledge) yang merupakan pemahaman istilah dan konsep keuangan yang meliputi istilah dan konsep tentang pembagian (division), nilai waktu uang (time value of money), bunga pinjaman yang dibayarkan (interest paid on a loan), perhitungan bunga plus saldo pinjaman (calculation of interest plus principle), bunga majemuk (compound interest), risiko dan pengembalian (risk and return), definisi inflasi (definition of inflation), dan diversifikasi (diversification); $\quad$ (2) perilaku 
keuangan yang berkaitan dengan masalah berpikir sebelum melakukan pembelian (thinking before making a purchase, paying bills on time), penganggaran (budgeting), menabung (saving), meminjam untuk memenuhi kebutuhan (borrowing to make ends meet); dan (3) sikap keuangan (financial attitude) yang berkaitan dengan Sikap terhadap uang (Attitude towards money) dan Perencanaan untuk masa depan (Planning for the future).

Nyamute dan Maina (2010) dalam penelitiannya tentang hubungan antara literasi keuangan dengan manajemen keuangan personal menyimpulkan bahwa terdapat perbedaan yang signifikan manajemen keuangan personal dari responden yang melek (literate) keuangan dengan yang tidak. Literasi keuangan memiliki apresiasi dan aflikasi yang lebih baik terhadap manajemen keuangan (financial management).

\section{Hubungan Antara Karakteristik Sosial Ekonomi dengan Manajemen Keuangan Personal}

Selain literasi keuangan, masih banyak faktor yang mempengaruhi manajemen keuangan personal. Salah satu di antara faktor tersebut adalah karakteristik sosial ekonomi atau Kapoor, Dlabay \& Hughes (2012) menyebutnya dengan istilah faktor personal.

Menurut Kapoor, Dlabay \& Hughes (2012), faktor personal seperti usia, pendapatan, ukuran keluarga, dan lain-lain dapat mempengaruhi pola pembelanjaan dan tabungan seseorang. Pola pembelanjaan dan tabungan seseorang ini merupakan bagian dari manajemen keuangan personal.

\section{METODE PENELITIAN}

Penelitian ini bertujuan untuk
Menggambarkan literasi keuangan dan manajemen keuangan personal Pegawai Negeri Sipil daerah (PNS daerah) di Kabupaten Kuningan serta mengkaji bagaimana pengaruh variabel karakteristik sosial ekonomi terhadap literasi keuangan dan manajemen keuangan personal, serta bagaimana pengaruh literasi keuangan terhadap manajemen keuangan personal. Berdasarkan tujuan penelitian tersebut, maka metode penelitian yang digunakan dalam penelitian ini adalah metode deskriptif dan metode verifikatif.

Populasi dalam penelitian ini adalah seluruh Pegawai Negeri Sipil Daerah yang masih aktif di Kabupaten Kuningan, oleh karena itu, yang menjadi unit analisis adalah Pegawai Negeri Sipil daerah (PNS daerah). Berdasarkan data yang ada menunjukan jumlah Pegagawai Negeri Sipil Daerah di kabupaten kuningan sebanyak 14.538 pegawai yang terdistribusi dalam 37 Organisasi perangkat daerah (OPD) atau Satuan Kerja Perangkat Daerah (SKPD).

Untuk menentukan ukuran sampel digunakan Rumus Slovin dengan tingkat kesalahan sebesar 5\%, sehingga diperoleh hasilnya sebesar 390 Responden. Teknik pengambilan sampel menggunakan metode Cluster Proportional Random Sampling.

Pengumpulan data dilakukan dengan menggunakan kuesioner. Kuesioner yang digunakan dalam penelitian ini adalah modifikasi dari kuesioner yang pernah digunakan oleh peneliti sebelumnya. Kuesioner yang digunakan untuk mengukur financial knowledege, financial behavior, dan financial attitude adalah modifikasi kuesioner dari OECD INFE (2011). Kuesioner yang digunakan untuk mengukur manajemen keuangan personal (personal financial management) adalah modifikasi 
kuesioner dari Rajna A. R. Anthony (2011).

Ada dua Rancangan Analisis Data yang digunakan dalam penelitian ini, yaitu Analisis Deskriptif dan analisis verifikatif. Analisis deskriptif digunakan untuk mengetahui gambaran tentang literasi keuangan dan manajemen keuangan personal Pegawai Negeri Sipil Daerah di Kabupaten Kuningan.

Analisis verifikatif digunakan untuk mencapai tujuan inti dari penelitian ini, yaitu untuk mengetahui pengaruh variabel sosial ekonomi terhadap literasi keuangan serta pengaruh variabel literasi keuangan terhadap manajemen keuangan personal. Dalam analisis verifikatif ini digunakan teknik analisis regresi logistik (logistic regression). Adapun model regresi logistik dalam penelitian ini adalah:

\section{Model 1}

$$
\begin{aligned}
g(\mathbf{x}) & =\ln \left(\frac{\pi(\mathbf{x})}{1-\pi(\mathbf{x})}\right) \\
& =\beta_{0}+\beta_{1} U+\beta_{J K 1} D J K_{1}+\beta_{T P 1} D T P_{1}+\beta_{T P 2} D T P_{2}
\end{aligned}
$$
$\begin{aligned} \pi= & \text { peluang bahwa responden } \\ & \text { memiliki tingkat financial } \\ & \text { knowledge (model 1), financial }\end{aligned}$ behavior (model 2), financial attitude (model 3), dan manajemen keuangan personal (model $4 \& 5$ ) yang lebih tinggi (di atas rata-rata).

$\mathrm{JK}=1$ jika responden laki-laki, 0 jika perempuan

$\mathrm{U} \quad=$ Umur responden

$\mathrm{TP} 1=1$ jika pendidikan responden S1, 0 jika bukan

$\mathrm{TP} 2=1$ jika pendidikan responden S2, dan S3, 0 jika bukan

$\mathrm{TT}=1$ jika reponden tinggal di perkotaan, 0 jika di pedesaan

$\mathrm{GG} 1=1$ jika golongan gaji responden golongan II , 0 jika bukan

GG2 = 1 jika golongan gaji responden golongan III, 0 jika bukan

GG3 = 1 jika golongan gaji responden golongan IV, 0 jika bukan

$\mathrm{PD}=$ Pendapatan responden

$\mathrm{Fk}=$ tingkat pengetahuan keuangan

$\mathrm{Fb}=$ tingkat perilaku keuangan

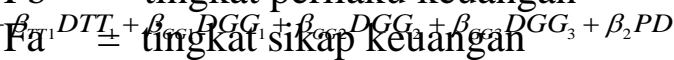

Model 2

$$
\begin{aligned}
& g(\mathbf{x})=\ln \left(\frac{\pi(\mathbf{x})}{1-\pi(\mathbf{x})}\right) \quad \text { HASIL PENELITIAN DAN }
\end{aligned}
$$

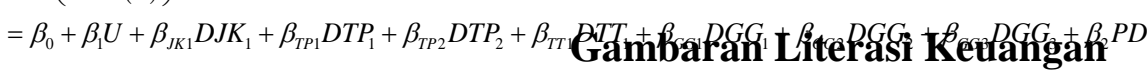

Model 3

Berdasarkan skor rata-rata hasil

$$
g(\mathbf{x})=\ln \left(\frac{\pi(\mathbf{x})}{1-\pi(\mathbf{x})}\right)
$$
penilaian tentang literasi keuangan, dapat digambarkan bahwa:

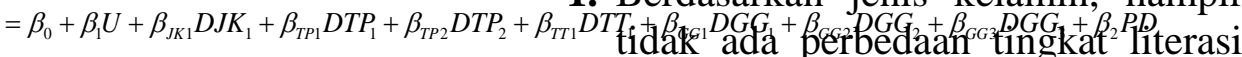

Model 4

Model 5

$$
\begin{aligned}
g(\mathbf{x}) & =\ln \left(\frac{\pi(\mathbf{x})}{1-\pi(\mathbf{x})}\right) \\
& =\beta_{0}+\beta_{1} F K+\beta_{2} F B+\beta_{3} F A
\end{aligned}
$$

$$
g(\mathbf{x})=\ln \left(\frac{\pi(\mathbf{x})}{1-\pi(\mathbf{x})}\right)
$$

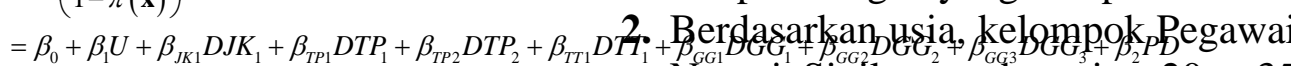$$
\text { Negeri Sipil yang berusia } 20 \text { - } 35
$$$$
\text { tahun dan yang berusia } 36-50 \text { tahun }
$$$$
\text { memiliki tingkat literasi keuangan }
$$

Dimana: Sipil perempuan dengan Pegawai Negeri Sipil laki-laki. Pegawai Negeri Sipil perempuan dan Pegawai Negeri Sipil laki-laki memiliki tingkat pengetahuan, perilaku dan sikap keuangan yang hampir sama.

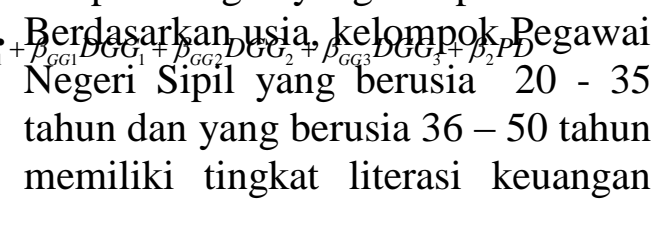
keuangan antara Pegawai Negeri 
yang sama tinggi. Mereka memiliki tingkat pengetahuan, perilaku dan sikap keuangan yang hampir sama. Kelompok Pegawai Negeri Sipil yang berusia di atas 50 tahun memiliki tingkat literasi keuangan yang paling rendah.

3. Berdasarkan tempat tinggal, Pegawai Negeri Sipil yang bertempat tinggal di perkotaan memiliki tingkat literasi keuangan yang lebih tinggi dibanding dengan Pegawai Negeri Sipil yang bertempat tinggal di pedesaan.

4. Berdasarkan tingkat pendidikan, kelompok Pegawai Negeri Sipil yang berpendidikan S-2 dan S3 memiliki tingkat literasi keuangan yang lebih tinggi dibanding dengan kelompok Pegawai Negeri Sipil yang berpendidikan dibawahnya. Kelompok Pegawai Negeri Sipil yang berpendidikan SD, SLTP, dan SLTA memiliki tingkat literasi keuangan yang paling rendah.

5. Berdasarkan golongan dan ruang gaji, secara total kelompok Pegawai Negeri Sipil yang bergolongan dan ruang gaji III memiliki tingkat literasi keuangan yang paling tinggi, dan Kelompok Pegawai Negeri Sipil yang bergolongan dan ruang gaji II memiliki tingkat literasi keuangan yang paling rendah. Secara per dimensi kelompok Pegawai Negeri Sipil yang bergolongan dan ruang gaji II memiliki tingkat literasi yang paling rendah dalam financial knowledge dan financial attitudenya, sementara kelompok Pegawai Negeri Sipil yang bergolongan dan ruang gaji IV memiliki tingkat literasi keuangan yang paling rendah dalam hal financial behavior-nya.

6. Berdasarkan tingkat pendapatan, kelompok Pegawai Negeri Sipil yang berpendapatan di atas Rp 5.000.000,00 memiliki tingkat literasi keuangan yang paling tinggi. Kelompok Pegawai Negeri Sipil yang berpendapatan antara Rp $3.000 .000,00$ - Rp 5.000.000,00 memiliki tingkat literasi keuangan yang paling rendah.

\section{Gambaran Manajemen Keuangan Personal}

Berdasarkan skor rata-rata hasil penilaian tentang manajemen keuangan personal, dapat digambarkan bahwa:

1. Berdasarkan jenis kelamin, tidak ada perbedaan antara Pegawai Negeri Sipil laki-laki dan Pegawai Negeri Sipil perempuan dalam hal pengelolaan keuangan personalnya.

2. Berdasarkan usia, kelompok usia 20 - 35 tahun dan kelompok usia 36 50 tahun memiliki kemampuan pengelolaan keuangan personal yang lebih tinggi dibanding dengan kelompok usia di atasnya.

3. Berdasarkan tempat tinggal, Pegawai Negeri Sipil yang bertempat tinggal di perkotaan memiliki tingkat manajemen keuangan personal yang lebih baik dibanding dengan Pegawai Negeri Sipil yang bertempat tinggal di pedesaan.

4. Berdasarkan tingkat pendidikan, Pegawai Negeri Sipil yang berpendidikan S-2 dan S-3 memiliki tingkat manajemen keuangan personal yang lebih baik dibanding dengan Pegawai Negeri Sipil yang berpendidikan lainnya. Pegawai Negeri Sipil yang berpendidikan SD, SLTP, dan SLTA memiliki tingkat manajemen keuangan personal yang paling rendah.

5. Berdasarkan golongan dan ruang gaji, kelompok Pegawai Negeri Sipil yang memiliki golongan dan ruang gaji IV memiliki tingkat manajemen keuangan personal yang lebih tinggi dibanding dengan kelompok Pegawai Negeri Sipil yang memiliki golongan 
Tabel 14

Hasil penaksiran koefisien regresi Pengaruh Karakteristik Sosial Ekonomi Terhadap Financial Behavior

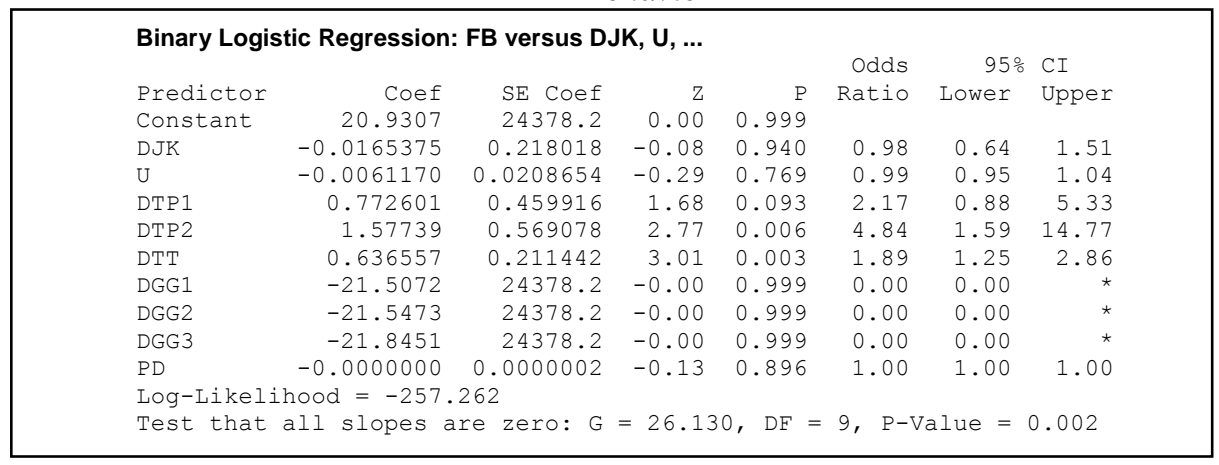

\section{Uji Secara Simultan}

Berdasarkan tabel di atas, hasil pengujian menunjukkan terjadinya penolakan terhadap $\mathrm{H}_{0} \quad$ karena $G>\chi_{\alpha . p}^{2}(26,130>16,92)$ atau $p$-value $<\alpha \quad(0,002<0,05) \quad$ sehingga dapat dikatakan bahwa variabel karakteristik sosial ekonomi secara bersama-sama berpengaruh sinifikan terhadap financial behavior.

\section{Uji Secara Parsial}

Berdasarkan hasil pengujian dan statistik uji untuk variabel tingkat pendidikan (TP2) dan tempat tinggal (TT), $W_{i}^{\sim} \geq Z_{\alpha / 2}(2,77$ dan $3,01>1,96)$ atau $p$-value $<\alpha(0,006$ dan
$0,003<0,05)$, sementara untuk variabel lainnya terjadi sebaliknya. Dengan demikian dapat dikatakan bahwa hanya variabel tingkat pendidikan dan tempat tinggal yang berpengaruh signifikan terhadap financial behavior, sedangkan variabel lainnya (umur, jenis kelamin, golongan gaji dan pendapatan) berpengaruh secara tidak signifikan terhadap financial behavior.

\section{Pengaruh Karakteristik Sosial Ekonomi Terhadap Sikap Keuangan (Financial Attitude)}

Hasil penaksiran parameter/ koefisien regresi dapat diilihat pada tabel berikut:

Tabel 15

Hasil Penaksiran Koefisien Regresi Pengaruh Karakteristik Sosial Ekonomi Terhadap Financial Attitude

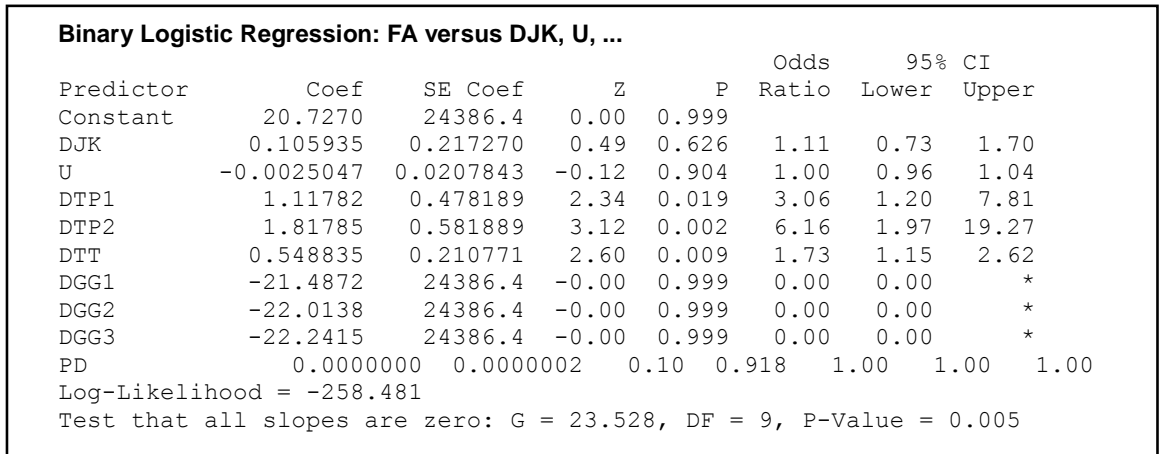

Uji Secara Simultan

Hasil Pengujian menunjukkan terjadi penolakan terhadap $\mathrm{H}_{0}$ karena $G>\chi_{\alpha . p}^{2}$ $(23,528>16,92)$ atau $p$-value $<\alpha$ 
$(0,005<0,05)$ sehingga dapat dikatakan bahwa variabel karakteristik sosial ekonomi secara bersama-sama berpengaruh terhadap financial attitude.

\section{Uji Secara Parsial}

Berdasarkan hasil pengujian dan statistik uji untuk variabel tingkat pendidikan (TP1 dan TP2) dan tempat tinggal (TT), $W_{i}^{\sim} \geq Z_{\alpha / 2}(2,34,3,12$, dan $2,60>1,96)$ atau $p$-value $<\alpha$ $(0,019, \quad 0,002 \quad$ dan $\quad 0,009<0,05)$, sementara untuk variabel lainnya terjadi sebaliknya. Dengan demikian dapat dikatakan bahwa hanya variabel tingkat pendidikan dan tempat tinggal yang berpengaruh secara signifikan terhadap financial attitude, sedangkan variabel lainnya (umur, jenis kelamin, golongan gaji dan pendapatan) berpengaruh secara tidak signifikan terhadap financial attitude.

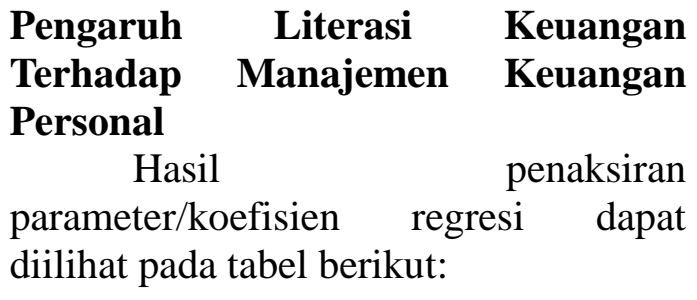

Tabel 16

Hasil Penaksiran Koefisien Regresi Pengaruh Literasi Keuangan Terhadap Praktek Manajemen Keuangan

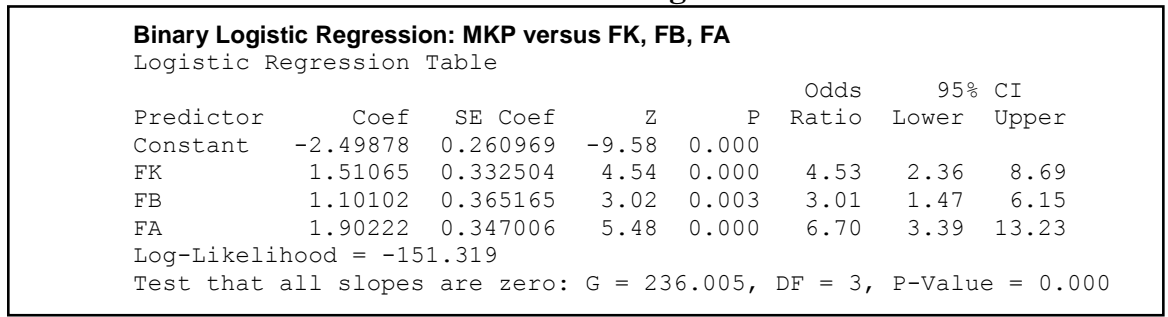

\section{Uji Secara simultan}

Berdasarkan tabel di atas hasil pengujian menunjukkan terjadinya penolakan terhadap $\mathrm{H}_{0}$ karena $G>\chi_{\alpha . p}^{2}$ $(236,005>7,81)$ atau p-value $<\alpha$ $(0,000<0,05)$ sehingga dapat dikatakan bahwa variabel financial knowledge, financial behavior dan financial attitude secara bersama-sama berpengaruh signifikan terhadap manajemen keuangan personal.

\section{Uji Secara Parsial}

Berdasarkan hasil pengujian dan statistik uji untuk variabel financial knowledge (FK), financial behavior
(FB) dan financial attitude (FA), $W_{i}^{\sim} \geq Z_{\alpha / 2}(4,54,3,02$ dan $5,46>1,96)$ atau $p$-value $<\alpha(0,000,0,003$ dan $0,000<0,05)$. Dengan demikian dapat dikatakan bahwa variabel financial knowledge, financial behavior dan financial attitude berpengaruh secara signifikan terhadap manajemen keuangan personal.

\section{Pengaruh Karakteristik Sosial Ekonomi Terhadap manajemen Keuangan Personal}

Hasil penaksiran parameter/ koefisien regresi dapat dilihat pada tabel berikut: 
behavior) dan sikap keuangan (attitude).

5. Variabel karakteristik sosial ekonomi secara bersama berpengaruh signifikan terhadap manajemen keuangan personal (personal financial manajemen). Tingkat pendidikan merupakan variabel yang sangat mempengaruhi tinggi rendahnya tingkat manajemen keuangan personal (personal financial manajemen).

\section{Saran}

1. Bagi pemerintah atau para pemangku kepentingan dalam upaya meningkatkan kesejahteraan masyarakat selain berupaya meningkatkan pendapatan masyarakat juga perlu diupayakan peningkatan kemampuan masyarakat dalam melakukan pengelolaan keuangan personalnya.

2. Dalam upaya meningkatkan tingkat literasi keuangan masyarakat perlu dilakukan upaya peningkatan tingkat pendidikan, baik pendidikan yang bersifat umum maupun pendidikan yang bersifat khusus yaitu pendidikan yang menyangkut masalah literasi keuangan seperti yang telah dilakukan di negaranegara lain.

3. Bagi peneliti-peneliti selanjutnya yang berminat meneliti hal yang sama, untuk melakukan penelitian dalam lingkup masyarakat yang lebih luas dan dengan variabel yang lebih banyak.

\section{DAFTAR PUSTAKA}

Alessie, Rob, Annamaria Lusardi, and Maarten van Rooij. 2008. Financial Literacy, Retirement Planning, and Household Wealth. NBER Working Paper, No. 15350.

Almenberg, Johan and Jenny SäveSöderberg. 2011. Financial Literacy and Retirement Planning in Sweden.
CeRP Working Paper, No. 112, Turin (Italy).

ANZ .2008. ANZ survey of adult financial literacy in Australia, (The Social Research Centre) ANZ Banking Group, Melbourne.

Atkinson, A. and F. Messy. 2012, Measuring Financial Literacy: Results of the OECD / International Network on Financial Education (INFE) Pilot Study. OECD Working Papers on Finance, Insurance and Private Pensions, No. 15, OECD Publishing. http://dx.doi.org/10.1787/5k9csfs90fr4-en.

Avard, S., Manton, E., English, D., \& Walker, J. 2005. The financial knowledge of college freshmen. College Student Journal, 39, 321339.

Ayu K, Maya S \& Rofi R. 2010. Analisis Tingkat Literasi Keuangan di kalangan mahasiswa dan faktorfaktor yang mempengaruhinya survey pada mahasiswa Universitas Pendidikan Indonesia $<$ http://www.file.upi.edu/Direktori L-FPEB Prodi Manajemen.html>

Banks, James, Cormac O’Dea, and Zoë Oldfield. 2009. Cognitive function, numeracy and retirement saving trajectories. Economic Journal 120 (November): F381-F410.

Beal, Diana and Sarath Delpachitra. 2003. Financial Literacy among Australian University Students. Economic Papers 22 (January): 6578.

Beck, Thorsten., Asli Demirgüç-Kunt, and Ross Levine. 2009. A new database on financial development and structure. Policy Research Working Paper Series, No. 2146, The World Bank.

Bowen, Cathy. 2003. Financial Knowledge of Teens and Their Parents. Financial Counseling and 
Planning 13 (February): 93-102.

BPS. 2012. Jawa Barat Dalam Angka.

BPS. 2012. Kuningan dalam Angka.

Braunstein, S., \& Welch, C. 2002.

Financial literacy: An overview of practice, research and policy. Federal Reserve Bulletin, 445-457.

Campbell, John. 2006. Household Finance. Journal of Finance 61 (August): 553-1604.

Chen, Haiyang, and Ronald P. Volpe. 1998. An Analysis of Personal Financial Literacy among College Students. Financial Services Review 7: 107-128.

Chen, Haiyang, and Ronald P. Volpe. 2002. Gender Differences in Personal Financial Literacy Among College Students. Financial Services Review 11(March): 289-307.

Christelis, Dimitris, Tullio Jappelli, and Mario Padula. 2010. Cognitive abilities and portfolio choice. European Economic Review 54 (January): 18-39.

Cole, Shawn, Thomas Sampson, and Bilal Zia. 2008. Money or knowledge? What drives the demand for financial services in developing countries? Harvard Business School Working Paper, No. 09-117.

Courchane, Marsha J., Adam Gailey and Peter Zorn. 2008. Consumer Credit Literacy: What Price Perception? Journal of Economics and Business 60 (January-February): 125-138.

Delavande, Adeline, Susann Rohwedder, and Robert Willis. 2008. Preparation for Retirement, Fnancial Literacy and Cognitive Resources. Michigan Retirement Research Center Working Paper, No. 190.

Eagly, A. \& Chaiken, S. 1993. The psychology of attitudes. Toronto: Harcourt Brace Jovanovich College.

Falahati, Leila and Laily H. Paim. 2011. Toward a Framework of Determinants of Financial
Management and Financial Problem Among University students. African Journal of Business Management Vol. 5(22), pp. 9600-9606, 30 September, 2011. http://www.academicjournals.org/AJ BM DOI: 11.5897/AJBM11.1293.

Guiso, Luigi, and Tullio Jappelli. 2005. Awareness and Stock Market Participation. Review of Finance 9 (December): 537-567.

Guiso, Luigi, and Tullio Jappelli. 2008. Financial literacy and portfolio diversification. CSEF Working Paper, No. 212

Gujarati, Damodaran N., and Porter, Dawn C. 2009. Basic Econometrics. Fifth Edition. McGraw Hill. New York.

Hilgert, M. A., Hogarth, J. M., \& Beverly, S. G. 2003. Household financial management: The connection between knowledge and behavior. Federal Reserve Bulletin (July), 309-322.

Hogarth, Jeanne M., and Kevin H. O'Donnell. 1999. Banking Relationships of Lower-income Families and the Governmental Trend toward Electronic Payment. Federal Reserve Bulletin 86 (July): 459-473.

Hogarth, J.M. 2002. Financial literacy and family and consumer sciences. Journal of Family \&Consumer Sciences, 94(1), 15-28.

Huston, Sandra. 2010. Measuring Financial Literacy. The Journal of Consumer Affairs 44 (summer): 271275.

Jodi L. Parrotta and Phyllis J. Johnson.1998. The impact of financial attitudes and knowledge on financial management and satisfaction of recently married individuals. Association for Financial Counselling and Planning, Vol. 9(2). Johan Almenberg and Jenny Sa“ Ve-So“ 
Derbergh. 2011. Financial literacy and retirement planning in Sweden. PEF, 10 (4) : 585-598, October, 2011. Cambridge University Press 2011 , doi:10.1017/S1474747211000497.

Jones, S. K., \& Stine, J. B. 2005. Constant mix portfolios and risk aversion. Financial Counseling and Planning, 16(2), 1-8.

Joo, S., Grable, J. E., \& Bagwell, D. C. 2003. Credit card attitudes and behaviors of college students. College Student Journal, 37, 405419.

Jorgensen,B.L., \& Savla, J. 2010. Financial Literacy of Young Adult: The Importance of Parental Socialization. Family Relation, 59, 465-478.

Jump\$tart Coalition for Personal Financial Literacy. 2007. National standards in k-12 personal financial education (3rd ed.). Available from Jump\$tart Coalition ${ }^{\circledR}$ for Personal Financial Literacy Web site, http://www.jumpstart.org

Jump\$tart Coalition.2008. Survey of Personal Financial Literacy Among college students. May 2008, http://www.

Jum\$tart.org/fileindex.cfm.

Kapoor, Jack R, Dlabay, Les R, and Hughes, Robert J. 2012. Personal Finance. Tenth edition. mcGraw Hill. New York.

Kharchenko, olga. 2011. Financial literacy in Ukraina: determinants and implication for saving behavior. Thesis, Kyiv School of Economics.

Kim, Jinhee. 2001. Financial Knowledge and Subjective and Objective Financial Well-being. Consumer Interests Annual 47.

Klapper, Leora, and Georgios A. Panos. 2011. Financial Literacy and Retirement Planning in View of a Growing Youth Demographic: the
Russian Case. CeRP Working Paper, No. 114/11.

Lusardi, Annamaria and Olivia S. Mitchell. 2006. Financial Literacy and Planning: Implications for Retirement Wellbeing. MRRC Working Paper, No. 2006-144.

Lusardi, Annamaria and Olivia S. Mitchell. 2008. Planning and Financial Literacy:How Do Women Fare?American Economic Review 98 (February): 413-417.

Lusardi, Annamaria A. and Peter Tufano. 2009. Debt Literacy, Financial Eexperiences, and Overindebtedness. NBER Working Paper, No. 14808.

Mandell, Lewis. 2004. Financial Literacy: Are We Improving? Results of the 2004 National Jump\$tart Survey. Washington, D.C.: Jump\$tart Coalition for Personal Financial Literacy.

Mandell, Lewis. 1998. Our Vulnerable Youth: The Financial Literacy of American 12th Graders. Washington D.C.: Jump\$tart Coalition for Personal Financial Literacy.

Mandell, L. (2006). Financial literacy: Improving education. Washington, DC: Jump\$tart Coalition for Personal Financial Literacy.

Mandell, Lewis, and Linda S. Klein. 2007. Motivation and financial literacy. Financial Services Review 16: 105-116.

Mandell, L. 2008. Financial literacy of young American adults: Results of the 2008 National Jump\$tart Coalition survey of high school seniors and college students. Washington, DC: Jump\$tart Coalition for Personal Financial Literacy.

Mandell, L. 2009. The financial literacy of young American adults: results of the 2008 National Jump\$tart Coalition survey of high school 
seniors and college students. Washington, D.C.: Jumpstart Coalition.

Markovich, C. A., \& DeVaney, S. A. 1997. College seniors' personal finance knowledge and practices. Journal of Family and Consumer Sciences, 89, 61-65.

McArdle, John J., James P. Smith, and Robert Willis. 2009. Cognition and Economic Outcomes in the Health and Retirement Survey. NBER Working Paper, No. 15266.

Monticone, Chiara. 2010. How Much Does Wealth Matter in the Acquisition of Financial Literacy? The Journal of Consumer Affairs 44 (February): 403-422

Nachrowi Djalal Nachrowi dan Hardius Us,man. 2002. Penggunaan Teknik Ekonometri. PT RajaGrafindo Persada. Jakarta.

Noctor, Michael, Sheila Stoney, and Robert Stradling. 1992. Financial Literacy: a Discussion of Concepts and Competences of Financial Literacy and Opportunities for its Introduction into Young People's Learning. NFERReport for the National Westminster Bank. London, The United Kingdom.

Nyamute and Maina. 2010. Effect Of Financial Literacy On Personal Financial Management Practices: A Case Study Of Employees Of Finance And Banking Institutions. Department Of Finance And Accounting,School Of Business, University Of Nairobi.

OECD. 2005. Improving financial literacy: Analysis of issues and policies, Organisation for Economic Cooperation and Development. Paris: OECD Publishing.

OECD. 2011. Measuring Financial Literacy: Quetionnaire and Guidance Note for Conducting and
Internationally Comparable Survey of Financial Literacy. Paris: OECD Publishing.

OJK. 2013. Strategi Nasional Literasi Keuangan Indonesia. Otoritas Jasa Keuangan.

Peraturan Pemerintah Republik Indonesia Nomor 22 Tahun 2013.

Peress, Joël. 2004. Wealth, information acquisition, and portfolio choice. The Review of Financial Studies 17 (March): 879-914.

Rajna A. R. Anthony. 2011. Knowledge, Attitude, Practice and Satisfaction on Personal Financial Management among the Medical Practitioners in the Public and Private Medical Services in Malaysia, Faculty of Medicine Universiti Kebangsaan Malaysia Kuala Lumpur.

Rajna, A. R, WP. Sharifah Ezat, Syed Al Junid and H. Moshiri .2011. Financial Management Attitude and Practice among the Medical Practitioners in Public and Private Medical Service in Malaysia. International Journal of Business and Management. Vol. 6, No. 8; August 2011.

Servon, Lisa J., and Robert Kaestner. 2008. Consumer Financial Literacy and the Impact of Online Banking on the Financial Behavior of LowerIncome Bank Customers. The Journal of Consumer Affairs 42 (February): 271-305.

Stango, Victor, and Jonathan Zinman. 2009. Exponential Growth Bias and Household Finance. Journal of Finance 64 (December): 2807-2849.

Sugiyono.2008. Metode Penelitian Bisnis, Bandung: Alfabeta.

Sudjarwo, H. 2004. Buku Pintar Kependudukan, Jakarta : Gramedia Widiasarana Indonesia.

Sulaeman Rahman Nidar and Sandi Bestari. 2012. Personal Financial Literacy Among University Students. 
World Journal of Social Sciences Vol. 2. No. 4. July 2012. Pp. 162 171.

Vitt, Lois, Carol Anderson, Jamie Kent, Deanna Lyter, Jurg Siegenthaler, and Jeremy Ward. 2000. Personal Finance and the Rush to Competence: Financial Literacy Education in the US. National Field Study Commissioned by the Fannie Mae Foundation. Institute for SocioFinancial Studies.

Volpe, Ronald P., Chen, Haiyang, and Joseph J. Pavlicko. 1996. Investment Literacy among College Students: A Survey. Financial Practice and Education 6 (February): 86-94.

Warwick, J., \& Mansfield, P. 2000. Credit card consumers: College students' knowledge and attitude. Journal of Consumer Marketing, 17, 617-626.

http://dx.doi.org/10.1108/07363760010357 $\underline{813}$

Worthington, Andrew C. 2004. The Distribution of Financial Literacy in Australia. Discussion Paper, No. 185. Queensland University of Technology, Brisbane.

Worthington, AC 2006, Predicting Financial Literacy in Australia, Financial Services Review, 15(1), Spring 2006, 59-79.

Xiao, J. J. 2009. Applying behavior theories to financial behavior. In J. J. Xiao (Ed.), Handbook of consumer finance research (pp. 69-81). New York, NY: Springer. 